\title{
Editorial \\ Urban Land and Development Management in a Challenged Developing World: An Overview of New Reflections
}

\author{
Kwasi Gyau Baffour Awuah 1,*(D) and Raymond T. Abdulai ${ }^{2}$ \\ 1 School of Science, Engineering and Environment (SSEE), University of Salford, Manchester M5 4WT, UK \\ 2 School of Architecture, Planning and Landscape, Newcastle University, Newcastle NE1 7RU, UK; \\ raymond.abdulai@ncl.ac.uk \\ * Correspondence: k.a.b.gyau@salford.ac.uk
}

Citation: Awuah, K.G.B.; Abdulai, R.T. Urban Land and Development Management in a Challenged

Developing World: An Overview of New Reflections. Land 2022, 11, 129. https://doi.org/10.3390/land 11010129

Received: 31 December 2021

Accepted: 10 January 2022

Published: 14 January 2022

Publisher's Note: MDPI stays neutral with regard to jurisdictional claims in published maps and institutional affiliations.

Copyright: (C) 2022 by the authors. Licensee MDPI, Basel, Switzerland. This article is an open access article distributed under the terms and conditions of the Creative Commons Attribution (CC BY) license (https:// creativecommons.org/licenses/by/ $4.0 /)$.

\begin{abstract}
The urban development and management challenges of the developing world are well documented in the literature. However, the global built environment landscape is undergoing rapid changes. These changes are steeped in three fundamental imperatives, which have serious implications for the developing world. These imperatives are population growth and rising urbanisation; environmental challenges, particularly climate change and the quest to embrace sustainability as a panacea; and advances in technological development. This paper discusses these three imperatives with the view to teasing out their implications for urban development and management in the developing world. Consistent with the literature, the paper establishes that most of the population growth and rising urbanisation are occurring in the developing world, particularly Africa and Asia, and although these phenomena have the tendency to increase economic density and promote both private and public investment in urban development, especially construction/housing and related infrastructure activities, there are and will be several problems with them. These include land tenure insecurity, lack of access to decent affordable housing and the threat of destruction to heritage sites. Furthermore, environmental challenges such as poor waste management, and climate change are and will remain pressing issues requiring the adoption of sustainability credentials because of legislative requirements, moral suasion, and value addition. Despite the potential disruptive nature of technology with respect to some aspects of the built environment, it is recognised that advances in technology are essential to the achievement of optimal urban development and management outcomes in the developing world. The paper, therefore, recommends better understanding of the socio-economic, cultural, and political forces underlying urban growth in the developing world, factoring in technology and sustainability in urban development and management, and collaboration among relevant actors, particularly government and the private sector, for optimal outcomes.
\end{abstract}

Keywords: climate change; developing world; environment; urbanisation; sustainability; technology

\section{Introduction}

All human activities take place in space. Land is, thus, the basis of subsistence and an invaluable resource of humankind, which accounts for between $50 \%$ and $75 \%$ of the national wealth of many developing economies [1,2]. To obtain optimal outcomes, land is often combined with other resources such as labour, capital, and entrepreneurship, which all together are sometimes referred to as factors of production and which, in part, give rise to land development process [3-5]. The achievement of optimal outcomes from land does not only lie in its effective and efficient combination with other factors of production in terms of the land development process, but also its administration and management, together with the products, be they residential homes, office developments or infrastructure, amongst others.

Over the years, research and practice evidence have highlighted the weaknesses in urban land and development management in the developing world [6-14]. These weaknesses are manifested in low land registration rates; lack of compliance with development 
regulations; lack of access to land for development and insecure land and property rights for the marginalised such as the poor and women; poor land records; weak institutional capacities and land valuation systems; poor housing conditions; and inadequate infrastructure and its funding regimes among others. For example, across 10 countries in Africa, only $12 \%$ of women in comparison to $31 \%$ of men own land individually, a situation which resonates with other developing countries such as Peru (13\%), Honduras (14\%), Nicaragua $(20 \%)$, Bangladesh (23\%), and Haiti (24\%) [14]. Evidence also shows two main growing urban forms in the developing world, the largest being of an unregulated urban form characterised by informal settlements where land rights are often insecure and there is lack of adequate infrastructure and services, and new towns/gated communities/satellite cities, which are planned and provided with amenities [15-17].

However, the world's urban development and the built environment are undergoing rapid changes $[18,19]$ which have huge implications for the already precarious situation in the developing world and, therefore, call for new reflections of how urban land, development and the built environment in its entirety are perceived and managed for optimal outcomes. The changes taking place are fundamentally steeped in population growth and urbanisation, advances in technology and environmental challenges, particularly climate change and the need for sustainability or sustainable development [18-20], and more recently the emergence of the COVID-19 pandemic [21]. The primary purpose of this paper is to present an overview of the factors underlying the changing phase of global urban development and the built environment and their implications for the management of urban land and development in developing economies based on the extant literature. In so doing, the paper examines the factors in turns, commencing with population growth and urbanisation, followed by the environmental challenges and then advances in technology. Thereafter, the paper summarises the discussions and submits a potential way forward.

\section{Population Growth and Urbanisation}

Global population has witnessed significant growth since the 1950s. According to Population Matters [22], until the era of Napoleon, the Earth had a population of less than 1 billion at one single time. However, since the Second World War, the world's population has been increasing by a billion every $12-15$ years. The United Nations (UN) estimates the world's population at 7.9 billion and this population is expected to increase to 9.7 billion in 2050, up more than $50 \%$ from 6.1 billion in 2000 and thereafter to 10.9 billion in 2100 [23]. Concurrently, the world is also undergoing rapid urbanisation and urban growth. Since 2008 , more than $50 \%$ of the global population has been living in cities and towns. Currently, $55 \%$ of the global population lives in cities and towns, anticipated to increase to $68 \%$ by 2050 , an increase of 2.5 billion people over the current global urban population [23,24]. Earlier in 2012, UN-DESA estimated that the urban population will increase by $75 \%$ to 6.3 billion, from 3.6 billion [18]. Indeed, it was anticipated that by 2020, the 21st century's great migration to the cities would be well underway [18].

Most of the global population growth and urbanisation/urban growth will occur in Asia, Africa, Middle East, and Latin America. The UN Population Fund [25], for example, reports that nine countries, namely, India, Nigeria, Pakistan, the Democratic Republic of Congo, Ethiopia, Tanzania, Indonesia, Egypt, and the USA will make up over half the projected total population increase by 2050. Excepting the USA, all the remaining countries are in Africa, Asia, and Middle East. Similarly, it is noted that cities will be swelling across the fast-growing countries in Asia, Africa, the Middle East, and Latin America [18]. As can be seen from Figure 1, the combined quantum of Asia and Africa urbanisation since 2000 has been bigger than the rest of the world. In the case of Africa, the UN-Habitat [26] highlights that the continent's current population of 1.186 billion is expected to reach 1.679 billion ( $16 \%$ of the world's total) by 2030, assuming a growth rate of between $2 \%$ and $2.5 \%$. Furthermore, $55 \%$ of Africa's population is expected to reside in urban areas by 2050, with urban dwellers increasing from 471 million in 2015 to approximately 1.34 billion in 2050. In sub-Saharan Africa (SSA) alone, an estimated 70 million new residents are added to the urban area each 
year [23]. China is expected to experience the biggest migration of all into cities and towns, with as many as 1.5 million people moving to cities in search of a prosperous middleclass existence [18]. As with the anticipated China's urban population, the expected increase in developing countries' urban population will be mostly youthful population and there will be tremendous increase in middle-class population [18,27]. Indeed, global middle-class population is projected to increase by $180 \%$ between 2010 and 2040 . However, the highest proportion of middle-class people are set to live in Asia [18].

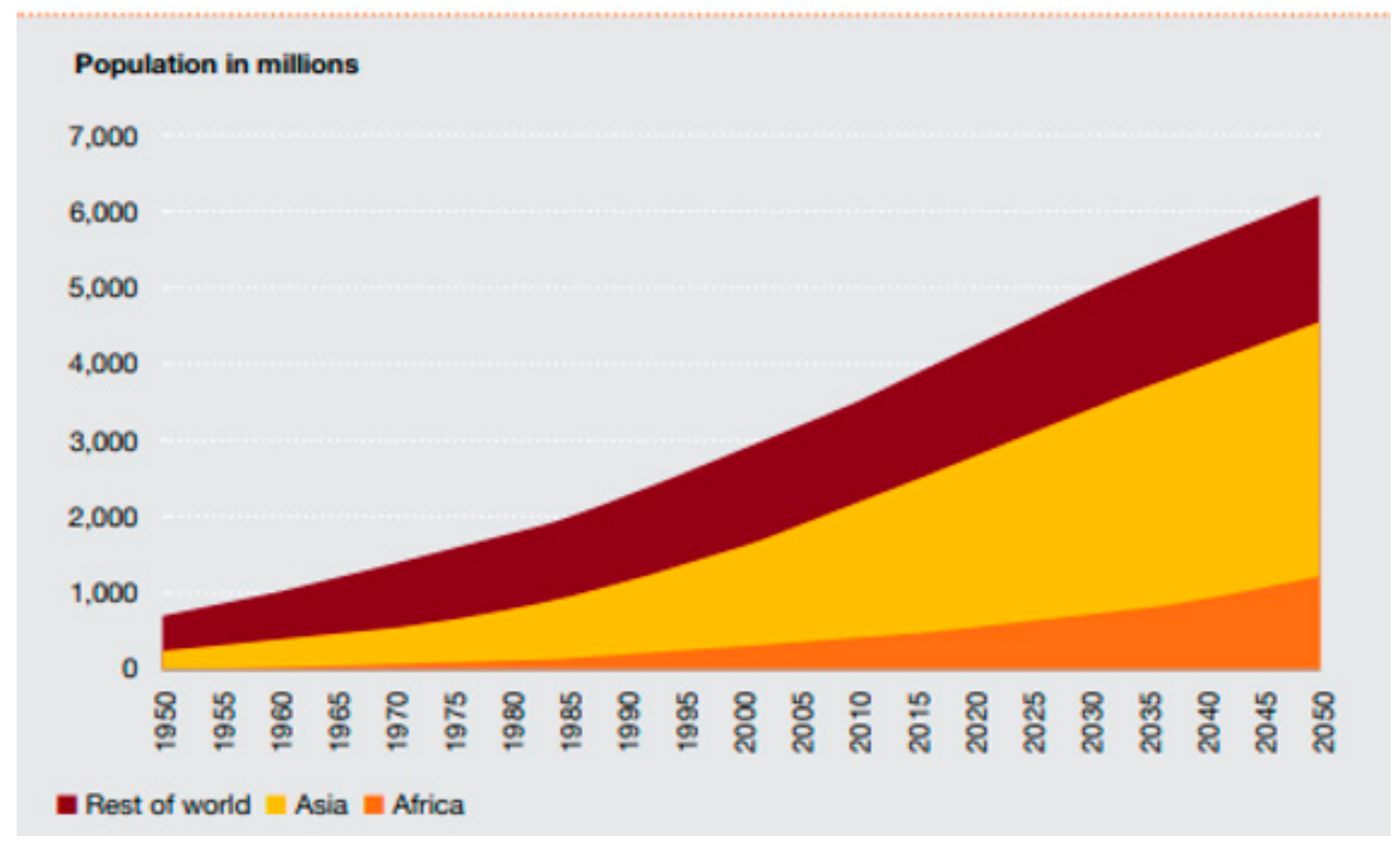

Figure 1. World Urban Population from 1950-2050. Source: PWC [18].

A clear implication of the current population and rising urbanisation across the world and particularly for the developing world is increase in demand for land developments and their associated infrastructure such as well-connected transport systems and basic services. This will likely give rise to extension of the frontiers of existing cities and the building of new ones [18]. By 2025, there will be 37 'megacities', up from 23 today, and 12 of these will be in emerging markets [18]. Furthermore, building activities are envisaged to be huge and the Global Construction 2025 [28] highlights that global construction output is anticipated to almost double to USD 15 trillion by 2025, up from USD 8.7 trillion in 2012. Emerging markets in Asia will be the fastest growing region, but SSA is expected to be the second highest. PricewaterhouseCoopers [18] reports that entirely new cities will be built in countries such as India and China. Although the current on-going urbanisation, if managed very well, could result in economic growth through increase in market activities and job creation from urban development activities among others in accordance with agglomeration theory [29], the nature of the demographic structure of the general and urban population growth in the developing world also suggests more housing will be needed [19,27] which may not be met. Indeed, it is estimated that the world will need two billion new homes over the next 80 years and most of the need will come from developing countries [30]. Earlier in 2016, the Unassuming Economist [31] reported a growing housing deficit in emerging and developing countries with evidence of housing backlog of some countries. For example, Namibia was reported to have a backlog of 110,000 housing units, which is growing at an annual rate of 3700 units, whilst Peru had a backlog of 1.9 million units. The Gambia, Uganda, Zambia, and Zimbabwe had a backlog of 50,000, 1.6 million, 1.5 million units and 1 million units, respectively, whilst housing demand in Tanzania was estimated at 
about 200,000 units annually. More recently, it is estimated that Pakistani Government must deliver around 400,000 housing units per annum for the next 15 to 20 years to face rising urbanisation, whilst Indonesia, the need is to add 820,000 to 920,000 new units every year to face similar demand [32]. Conversely, current backlog in the Democratic Republic of Congo (DRC) is estimated at almost four million units [33].

A critical issue with the anticipated urban developments is how they are going to be financed and even managed. It is now obvious that even if governments across the developing world were willing to finance and manage such developments, they are simply unable to do so because of the ever-increasing funding gap and the lack of capacity. Furthermore, although urban centres in the developing countries, particularly those in SSA, are becoming destinations of global investment [27,29], private capital inflows have not been extraordinary. In fact, the case of lack of infrastructure development in the developing world due to inadequate financing, for example, is well known in the literature [34-37]. In the case of the housing sector in Africa, for example, the Centre for Affordable Housing Finance in Africa [33] notes that financing remains a huge problem due to low incomes, high prices of homes and high mortgage interest rates. In a typical example, the cheapest formally built housing unit on the continent, a $32 \mathrm{~m}^{2}$ (a one-bedroom semi-detached unit) house developed by the Millard Fuller Foundation, at USD 8 275, was analysed from the financing standpoint. It was established that if the property were available for sale across the continent, financed by local mortgages, different percentages of the urban population within different countries might be able to afford the property, which varied between $79 \%$ of urban Kenyans and $12.74 \%$ of urban Rwandans. This financing problem has been exacerbated by the emergence of the COVID-19 pandemic. According to African Development Bank [38], 2020 was the worst economic year for Africa in the last 50 years and that to a large extent the emergence of the COVID-19 Pandemic culminated in the contraction of Africa's real gross domestic product (GDP) by $2.1 \%$ in 2020 with almost $50 \%$ of the countries on the continent suffering negative GDP growth rates, more than $-5 \%$. This implies savings in terms of revenues for urban developmental projects were hard hit by the pandemic and with the current discovery of the Omicron variant of the disease, which is being traced to Africa and has resulted in traveling bans on countries by some western countries, the situation may worsen soon.

The above being said, financing of urban developments, especially through private capital, is also a huge risk, even more so in developing countries where there continue to be transparency challenges $[27,39,40]$. Current analysis shows that the changing phase of the built environment across the world will result in intense competition among cities and only cities, which are able to endure the competition and take advantage of the changing imperatives will survive. It is, thus, anticipated that massive urban developments will occur, but such developments may not necessarily result in profit for investors in some cities as these cities may end up as ghost cities [18]. To manage some of the investment risks, investors particularly in the developing world have tended to focus on the middle-income population whose population, per the demographic trends, also continues to increase. This population mostly comprises young professionals who have appeal for certain kinds of real estate products. Indeed, the growing body of literature on urban development in the developing world shows that emerging developments often referred to as new towns, gated communities, satellite cities and new cities often target the middle-income population $[5,17,41]$. Even so, apart from the sustainability challenges of these new forms of development [17], access continues to be a problem due to increase in demand, resulting in high prices and rentals for such spaces.

Perhaps the greatest problem is not access to real estate products needed by the growing middle class, but other groups, especially the low-income group whose population also continues to grow and who need real estate products, particularly housing. Such populations often resort to alternative accommodation or housing in the informal sector. According to UN-Habitat [32], around 40\% and, in some cases, $75 \%$ of the population of fast-growing cities in developing countries is housed in squatter settlements without basic 
services. Furthermore, 881 million people in developing countries currently lives in slums compared to 689 million in 1990 and that across SSA, Asia and Pacific, Latin America, and Caribbean countries $59 \%, 28 \%$ and $21 \%$, respectively, of their urban populations live in slums. The point of interest is that the genesis of the lack of or inadequate access to housing and related services is poor access to land. Obviously, population increases and rising urbanisation resulting in demand for real estate products and the expansion of the frontiers of urban areas are occurring under market conditions. This implies that demand for and prices of land continue to soar in cities of developing countries; more so in peri-urban areas where most of the poor can access informal housing [42,43]. The commodification of land in the peri-urban areas is very intense and it is pricing out the poor from having access to developable land [42,43]. Even titles to their informal housing are not secure [44]. Indeed, according to the World Bank [44], most of the world's poor do not have legally registered property rights and around only $30 \%$ of their population have registered property rights compared to that of Africa (10\%), which is far less. This lack of access to developable lands by the poor is compounded by conflicts or litigation over land, dual or multiple tenure systems and poor land administration practices, among others [43]. Clearly, the foregoing housing situation in the developing world is an affront to the Sustainable Development Goal (SDG) 11, which considers decent and secure affordable housing as critical to poverty reduction and a means to improving equal opportunities and guarantee to sustainable growth.

Another observed ongoing effect of the urban development activities across the developing world borne out of urbanisation is the threat to the existence of important historical heritage sites. This threat is being exercised through the conversion of heritage sites by investors and other economic actors often under the guises of highest and best use into real estate development for private economic gains. The situation with heritage sites in Africa is a case in point [45]. Africa has 130 (SSA has 90) heritage sites on the prestigious World Heritage List out of a total of 1051 sites worldwide and the continent is generally recognised as underrepresented on the List [46]. Yet, Africa has the greatest number of sites on the United Nations Educational, Scientific and Cultural Organization (UNESCO)'s List of World Heritage in danger, accounting for $35.4 \%$ of the sites on this list. This is partly due to rapid urbanisation taking place on the continent [9,47], which is exacerbated by the inability of authorities in many parts of Africa to manage these heritage sites and buildings properly because of lack of requisite knowledge, data, and financial resources [45]. This situation also affects Target 11.4 of SDG 11, which acknowledges cultural heritage as central to sustainable development.

\section{The Environmental Challenge}

The idea to live in healthy environment continues to attract global attention. However, the world is faced with environmental challenges such as waste and climate change imperatives especially in cities and other urban areas. For example, apart from their following relevance in terms of revolutionising preservation: storage, longevity of numerous products; facilitating the ease of transporting products from factories to markets; and substituting for energy intensive materials such as iron and steel as well as their low cost [48], plastics continue to receive wider application and increase in production [49,50]. This application is evident in packaging, manufacturing of cars, aeroplanes, household electronics, medicines and industrial appliances used as finished products or inputs to further manufacturing of products as well as for building and construction [51]. However, whilst plastic production continues to increase at an alarming rate, managing the waste from plastics remains a huge problem with dire diverse impact. Evidence shows that for every person born since the 1950s, one tonne of plastic has been produced and less than a tenth of this has been recycled [48]. This leaves huge amounts of plastics indiscriminately discarded, ending up in rivers and oceans with devastating consequences for aquatic life. According to National Geographic [52], half of all plastics ever manufactured have been made in the last 15 years and production increased exponentially, from 2.3 million tons per 
annum in 1950 to 448 million tons per annum in 2015 and production is expected to double by 2050 , with serious consequences for the environment and socio-economic wellbeing. The COVID-19 pandemic is a significant contributory factor to the phenomenal increase in production as it has resulted in an exponential increase in the demand for plastic products such as hand sanitizers and facemasks. As Saadat et al. [53] note, most of the ordinary and surgical facemasks are made of plastic-based materials that are liquid-resistant and discarding empty bottles of hand sanitizers and masks adds up to a huge trail of waste in the environment.

Apart from the environmental destruction including its contribution to climate change (global plastic production emits 400 million tonnes of greenhouse gases each year), plastic waste is creating a growing public health emergency across the world through blocking waterways and drains, resulting in waterborne diseases, creating breeding grounds for disease-carrying flies, mosquitos, and vermin, etc., and harming livelihoods [48]. The UN Environment Programme (UNEP) [54] estimates that the economic costs (examples include revenue losses to fisheries, aquaculture, and marine tourism industries) associated with ocean-based consumer plastic pollution alone amounts to USD 13 billion every year. Climate change and its impact also remain a huge problem for the world. According to a BBC (2021) report, despite the pledges made at the recent UN Climate Change Conference (COP 26) in Glasgow, Scotland, the world is still nowhere near its goals on limiting global temperature rise and that the world is heading for $2.4^{\circ} \mathrm{C}$ of warming, far more than the $1.5{ }^{\circ} \mathrm{C}$ limit nations committed to.

However, most of these environmental challenges are rife in cities and urban areas or can be traced to them due to urbanisation, urban growth, and their associated activities. Cities occupy only 3\% of the Earth's surface yet house more than 55\% of the global population and account for half of all global waste [55]. Conversely, the World Bank [24] estimates that cities account for two thirds of global energy consumption and are responsible for more than $70 \%$ of greenhouse gas emissions. This implies that with the current and anticipated growth of urban development activities in cities and urban areas in developing countries due to urbanisation and urban growth, more waste will be generated in these areas. Indeed, the growth of plastic waste and its impacts are fastest and severe in developing countries, especially SSA and Asia [48,49]. The overall plastic waste growth in SSA is projected to triple by 2050 and between 400,000 and one million people die every year from illnesses and diseases caused by living near plastic pollution due to inadequate capacity for waste management exemplified by indiscriminate disposal and open burning plastic waste, instigating air pollution $[48,50]$. This is compounded by lack of awareness of the impact of pollutant effects of plastics and on better plastic waste management practices. For example, Nigeria and India are ranked 9th and 12th among the top 20 countries ranked by mass of mismanaged plastic waste [56]. The World Bank [57] also reports that the total quantity of waste generated in low-income countries is expected to increase by more than three times by 2050. The East Asia and Pacific region generate most of the World's waste, at 23\%, and the Middle East and North Africa region are producing the least in absolute terms, at $6 \%$. However, the fastest growing regions are SSA, South Asia, and the Middle East and North Africa, where, by 2050, total waste generation is expected to more than triple, double, and double, respectively. Since climate change is fundamentally a waste management problem, it is expected that the incidence of climate change will increase if the waste is not sustainably managed. Indeed, it is estimated that 1.6 billion tonnes of carbon dioxide $\left(\mathrm{CO}_{2}\right)$ equivalent greenhouse gas emissions were generated from solid waste treatment and disposal in 2016, a situation driven primarily by disposal of waste in open dumps and landfills without landfill gas collection systems. Food waste accounts for nearly 50\% of emissions. Solid waste-related emissions are anticipated to increase to 2.38 billion tonnes of $\mathrm{CO}_{2}$-equivalent per year by 2050 if no improvements are made in the sector [57].

In recognition of the growing environmental challenges that confront the world, there have been continuous calls for urban development and management activities to utilise sustainability credentials. These calls are informed by the international community proto- 
cols, agreements, and frameworks as well as national governments' pieces of legislation. The formulation of the SDGs by the UN in 2015 and the subsequent development of the New Urban Agenda (NUA), the UN's new framework for urban development in 2017 are clear examples. Indeed, Baffour Awuah [5] (p. 2) notes that:

"Essentially, the NUA is therefore a further confirmation of the global assurance towards the pursuit of sustainable urban development as a necessary action for the realisation of sustainable development in an integrated and coordinated way at the global, regional, national, subnational and local levels, with the participation of all relevant actors ensuring the implementation and localisation of the above initiatives particularly the 2030 Agenda for Sustainable Development with the SDGs and its target of Goal 11".

JLL [19] also acknowledges that there is now a new agenda for decarbonising the built environment and building back the world's future with the demand for greener and more sustainable places. The author further acknowledges that the demand is amplified by the COVID-19 pandemic and resonates very well with occupiers, investors, and city authorities as a heightened willingness to commit to tackling climate change. This means that not only will current and future developments in the urbanising global south require the meeting of sustainability credentials either by law or moral suasion, but also sustainability credentials will be key real estate value determinants for developments especially delivered through the formal processes. These sustainability credentials will be in areas such as building designs, energy usage and generally the use of green technologies among others.

\section{Technology}

The weak urban development and management arrangements in developing countries is well known. Challenges such as poor land administration and management as well as valuation systems, weak urban planning and governance regimes, weak institutional capacities and inefficient land and property markets among others are all well-rehearsed in the literature. Even if these arrangements were much robust, the application of technology particularly modern technology to the built environment and the way it is disrupting conventional real estate economics require that developing countries and the players in their built environment take keen interest as their cities and urban centres grow and expand their frontiers. The Internet of things (IoT) and the ever-increasing digital technologies including databases continue to see application in the built environment. This entails single uses or the combination of uses of technologies/databases such as Building Information Modelling (BIM), 3D modelling and data capture, computer-aided design (CAD), drones, structure form motion, laser scanners, digital photogrammetry, Global Positioning Systems (GPS), Global Information Systems, Digital Image Editing, Artificial Intelligence (AI) and Big Data [58,59]. Indeed, these technologies are a way to promote sustainable built environment and, according to PwC [18], technological advances will make eco-efficient building more practical as technologies underlying aspects of the built environment such as smart appliances, smart metres, smart building management systems, integrated distribution management systems and city-wide energy management systems are increasingly becoming more advanced and affordable. The authors further make the point that technology will be essential for real estate management in terms of, for example, adopting management techniques such as data warehouse and managing large volumes of data relating to lettings. Furthermore, technology will be critical in land administration and management. It is well documented that in the developing world, most land administration and management services are delivered in person rather than digitally, which hugely contributes to inefficiencies in the land administration and management systems. Additionally, the COVID-19 pandemic has even made it more compelling for the need to deploy technological techniques, especially, information and communication technologies in the delivery of land administration and management services.

Technology is also changing the economics of other sectors of the real estate industry such as, for example, the retail and office sectors. It is now becoming very clear that with the increasing patronage of online retail activities, particularly online shopping, and 
phenomena such as virtual meetings and engagements through videoconferencing/virtual platforms such as zoom, teams, and skypes among others, the demand for physical space for retailing and office is shrinking in developed Western economies, whilst the idea of siting warehouses close to customers is beginning to fade away. This situation has been exacerbated following the emergence of the COVID-19 pandemic in the latter part of 2019, which has necessitated the introduction of measures such as the need for people to stay at home and even work from home as much as possible to curtail the spread of the disease. Although uptake of technology in retailing activities and those which have otherwise been undertaken in offices is not widespread in most developing countries like in the Western developed economies, perhaps due to factors such as poor infrastructure base and income poverty, evidence shows that patronage is beginning to gain momentum. In fact, the high level of acceptability and usage of social media, including the use of mobile telephoning for financial transactions, is a clear example [60,61]. Consequently, as the economies of developing countries open and living conditions improve, situations such as online retailing activities are going to increase, and it would be very important for market players and other stakeholders to be cognisance of them if they really want to stay in business and be relevant. For sustainable urban management, the UN-Habitat [26] notes that advanced technology solutions and the effective use of data for evidence-based decisions have the possibility of providing a city's leadership with new methods and tools for effective urban development and service management. These tools, based on advanced urban modelling, Big Data, data analytics, AI, urban simulation, and collaborative visualisation, can, for instance, allow stakeholders to establish a comprehensive understanding of the current urban challenges and to evaluate the impact of various urban development options on the community, the economy, and the environment and then to choose sound solutions, giving due consideration to vulnerable communities and climate change adaptation.

\section{Summary, Implications and Way Forward}

Whilst several factors may impinge the global built environment, the three main factors of population growth and rising urbanisation, environmental challenges particularly climate change and the need for sustainable actions, and the growing technological advancement underlie the changing phase of the built environment. These factors and, for that matter, the changing phase, are having huge implications for urban development and management in the developing world. The discussions so far have established that most of the anticipated global population growth and rising urbanisation will take place in the developing world and whilst this will potentially increase economic density and promote investment, both private and public, in terms of urban development, particularly construction activities in the form of expansion or creation of new cities through housing and associated infrastructure development, there will be challenges with the phenomena given the limited capacity in developing countries to manage it. Housing development through private capital will be geared towards the growing middle class such as the young professionals with the taste for new town developments/gated communities. This implies that access to decent affordable housing and services for most of the population will continue to be a problem and that there will be rising levels of urban informality. Associated with this will be intense commodification of land and threat of destruction to heritage sites especially in the peri-urban areas, which could further fuel tenure insecurity for people within the low-income bracket. Furthermore, the problem of waste management and other environmental challenges leading to emission of greenhouse gases and climate change and their impact will continue to abound at an increasing level, which makes the call for decarbonisation and sustainability, not only by the international community and national governments but other stakeholders such as real estate investors and occupiers, imperative for developing countries. This call and its implementation are also seen as a way of adding value to investment. Fortunately, it is acknowledged that advances in technology, although they can disrupt aspects of the real estate market, could be effectively leveraged to better manage current and future urban development situations in developing countries. 
The above summary suggests that a great deal of work must be devoted to urban development and management in the developing world to achieve sustainable outcomes. That is not to say nothing has been done or is being done. Indeed, it is significant to note that since the end of the Cold War, new land reforms continue to take place across many developing countries [12]. These reforms predominantly focus on land governance and partly aim to improve access to land, tenure security and promote socio-economic progress by alleviating poverty, reducing inequality, increasing food security, and addressing climate change among other things. The cases of Zambia developing circular economy roadmaps to reduce its $\mathrm{CO}_{2}$ emissions in the context of its Nationally Determined Contribution (NDC) [62] and Côte d'Ivoire and Senegal identifying waste as one of the key sectors to achieve their NDCs because of the enormous opportunities it offers to emission reduction and job creation for the populace [63] are also key examples. Furthermore, it has been strongly recommended that adoption of land-based financing arrangements such as land value capture can help to mobilise substantial financial resources to fund urban infrastructure development to reduce the existing deficit $[37,64]$ and aspects of it are now being implemented especially in Latin American and Asian countries such as Brazil and India. Additionally, as noted previously, following the coming into being of the UN's SDGs, and NUA, which is a framework for urban development, enshrining the principles of the SDGs was adopted at UN Habitat III global summit in Quito, Ecuador in 2016 and some developing countries are now working towards the implementation of the principles. However, to obtain optimal outcomes from the changing phase of the urban development and management in developing countries, there is a need for thought-through and carefully planned strategies with realistic aims and sets of objectives, as well as the commitment to achieve them. This will require a clear understanding of the socio-economic, political, and cultural forces, both internal and external, underlying the nature of the growth and change taking place in individual cities and urban areas. For example, as stated elsewhere in this paper, entirely new cities will be created, especially in countries such as China whilst cities in other developing countries such as Nigeria, South Africa and Mexico are and will be growing rapidly, but since cities compete among themselves, particularly within their regions, to become dominant service centres, only those that are able to survive this competition attract investments. Therefore, there is a need for such understanding. This implies the need for more research into cities to provide the knowledgebase to help develop the platform for rolling out appropriate strategies.

From the summary of the discussion, it can also be surmised that there is a need to factor, to a large extent, technology and sustainability credentials in urban development and management in the developing world. However, as demonstrated in the main discussions, the physical technological investment and expertise levels in many developing countries leave much to be desired. Therefore, coupled with the need for more and regular research into cities, this will require huge investment not only in the acquisition of physical infrastructure, but training of the built environment professionals in the developing world. This may be in terms of development of entirely new curriculum or programmes of study or revalidation of existing ones and the actual training of students on the relevant programmes run by universities and other institutions of higher learning as well as professional bodies. Ultimately, the idea will be to deploy professionals with the required knowledge and skills set to apply appropriate technologies and up-to-date knowledge to make the most out of the changing phase of urban development and management in the developing world. There will also be a need for policy change to incorporate advances in technology, especially for countries which do not accept certain electronic ways of doing things, for example, electronic endorsement of land transactions.

Given that the urban development process and the management thereafter involve several actors broadly from the public/government, both national and local governments and the private sector including the third sector, there is a need for collaboration between these actors to ensure that sustainable urban development and management are achieved with clear optimal gains. There is no doubt that the ongoing changes in urban development 
and management in developing countries is attracting private capital and the projects involved although varying could be very huge requiring significant infrastructure including those of technology. Furthermore, it is anticipated that urban projects will meet sustainability credentials not only in environmental terms, but also social, for example, ensuring tenure security and access to decent housing for the poor, and economic. Consequently, governments can support the private sector around infrastructure development and engage the sector in fashioning and implementing sustainability protocols. Similarly, there could be collaboration between the public and private sectors, especially universities, industry, and government agencies, towards undertaking up-to-date research and training of urban development and built environment professionals.

Funding: This research received no external funding.

Conflicts of Interest: The authors declare no conflict of interest.

\section{References}

1. Bell, K.C. World Bank support for land administration and management: Responding to the challenges of the Millennium Development Goals'. In Proceedings of the 23rd FIG Congress, Munich, Germany, 8-13 October 2006.

2. Abdulai, R.T.; Obeng-Odoom, E.; Ochieng, V.M. (Eds.) Real Estate, Construction, and Economic Development in Emerging Market Economies: Past, Present, and Future; Routledge: London, UK, 2015.

3. Jowsey, E. Real Estate Economics; Palgrave Macmillan: Basingstoke, UK, 2011.

4. Squires, G., Heukens, E. (Eds.) International Approaches to Real Estate Development; Routledge: London, UK, 2014.

5. Baffour Awuah, K.G. Economic Incentives in Sub-Saharan African Urban Planning: A Ghanaian Case Study; Routledge: London, UK, 2021.

6. Payne, G. Urban Land Tenure and Property Rights in Developing Countries. 1996. Available online: File:///C:/Users/pms561 /Downloads/Urban_Land_Tenure_and_Property_Rights_In_Developin.pdf (accessed on 28 July 2020).

7. Toulmin, C. Securing land and property rights in Sub-Saharan Africa: The role of local institutions. Land Use Policy 2008, 26, 10-19. [CrossRef]

8. UN-Habitat. Planning Sustainable Cities: Policy Directions, Global Report on Human Settlements; Earthscan: London, UK, 2009.

9. UN-Habitat. The State of African Cities 2014: Re-Imagining Sustainable Urban Transitions; Earthscan: London, UK, 2014.

10. Watson, V. The planned city sweeps the poor away ... : Urban planning and 21st century urbanisation. Prog. Plan. 2009, 72, 151-193. [CrossRef]

11. Barlow, C. Meeting the challenges of land and property administration in developing countries. Fair Equitable 2015, 5, 3-15.

12. Ravnborg, H.M.; Spichiger, R.; Broegaard, R.B.; Pedersen, R.H. Land governance, gender equality and development: Past achievements and remaining challenges. J. Int. Dev. 2016, 28, 412-427. [CrossRef]

13. Nuhu, S. Peri-urban land governance in developing countries: Understanding the role, interaction, and power relation among actors in Tanzania. Urban Forum 2019, 30, 1-16. [CrossRef]

14. World Bank. Land. 2020. Available online: https://www.worldbank.org/en/topic/land (accessed on 28 July 2020).

15. Watson, V. African urban fantasies: Dreams or nightmares? Environ. Urban. 2015, 26, 215-231. [CrossRef]

16. Murray, M. Frictionless utopias for the contemporary urban age: Large-scale, master-planned redevelopment projects in urbanising Africa. In Mega-Urbanisation in the Global South: Fast Cities and New Urban Utopias of the Postcolonial State; Datta, A., Shaban, A., Eds.; Routledge: New York, NY, USA, 2017.

17. Keeton, R.; Provoost, M. (Eds.) To Build a City in Africa: A History and a Manual; Nai010: Rotterdam, The Netherlands, 2019.

18. PricewaterhouseCoopers (PwC). Real Estate 2020: Building the Future. 2014. Available online: https://www.pwc.com/sg/en/ real-estate/assets / pwc-real-estate-2020-building-the-future.pdf (accessed on 10 August 2021).

19. JLL. Real Estate Industry Has Accelerated Its Focus on Responsibility and Social Purpose. 2021. Available online: https: //www.jll.co.uk/en/newsroom/real-estate-industry-has-accelerated-its-focus-on-responsibility-and-social-purpose (accessed on 10 November 2021).

20. Designing Buildings. Industry Disruptions: 10 Ways Real Estate is Changing. 2021. Available online: https://www. designingbuildings.co.uk/wiki/Industry_Disruption:_10_ways_real_estate_is_changing (accessed on 10 November 2021).

21. Baffour Awuah, K.G.; Abdulai, R.T. Conclusions. In Sustainability and Real Estate in the Developing World; Abdulai, R.T., Baffour Awuah, K.G., Eds.; Emerald: Bingley, UK, 2021.

22. Population Matters. Population: The Numbers. 2021. Available online: https:/ / populationmatters.org/populationnumbers? gclid=EAIaIQobChMIjbrTi5Gx9AIV04ODBx3HlwO0EAAYAyAAEgJddvD_BwE (accessed on 10 November 2021).

23. UN-DESA. World Urbanisation Prospects 2018; UN-DESA: New York, NY, USA, 2018.

24. World Bank. Urban Development. 2020. Available online: https://www.worldbank.org/en/topic/urbandevelopment/ overview\#1 (accessed on 10 November 2021).

25. United Nations Population Fund (UNPF). Unfinished Business: The Pursuit of Rights and Choices for All. 2019. Available online: https: / / www.unfpa.org/swop-2019 (accessed on 20 November 2021).

26. UN-Habitat. Urbanisation and Development: Emerging Futures (World Cities Report); Earthscan: London, UK, 2016. 
27. Baffour Awuah, K.G.; Gyamfi-Yeboah, F. The role of task complexity in valuation errors analysis in a developing real estate market. J. Prop. Res. 2017, 34, 54-76. [CrossRef]

28. Global Construction 2025. Industrial Strategy: Government and Industry in Partnership. 2013. Available online: https:/ / assets.publishing.service.gov.uk/government/uploads/system/uploads/attachment_data/file/210099/bis-13-9 55-construction-2025-industrial-strategy.pdf (accessed on 10 November 2021).

29. Baffour Awuah, K.G.; Hammond, F.N.; Lamond, J.E.; Booth, C.A. Benefits of land use planning in Ghana. Geoforum 2014, 51, 37-46. [CrossRef]

30. Smith, S. The World Needs to Build More than Two Billion New Homes Over the Next 80 Years. The Conversation. 2018. Available online: https:/ / theconversation.com/the-world-needs-to-build-more-than-two-billion-new-homes-over-the-next80-years-91794 (accessed on 20 November 2021).

31. Unassuming Economist. Housing in Developed and Developing Countries. 2016. Available online: https://unassumingeconomist. com/2016/11/housing-in-developed-and-developing-countries/ (accessed on 20 November 2021).

32. UN-Habitat. Affordable Housing in Developing Countries. 2021. Available online: https://www.habitat.org/emea/about/whatwe-do/affordable-housing (accessed on 20 November 2021).

33. Centre for Affordable Housing Finance in Africa (CFAHA). Housing Finance in Africa: A Review of Africa's Housing Finance Markets (2021 Yearbook); CFAHA: Johannesburg, South Africa, 2021.

34. Devkar, G.A.; Mahalingam, A.; Deep, A.; Thillairajan, A. Impact of private sector participation on access and quality in provision of electricity, telecom, and water services in developing countries: A systematic review. Util. Policy 2013, 27, 65-81. [CrossRef]

35. African Development Bank (AfDB). An Integrated Approach to Provision of Infrastructure in Africa; AfDB: Abidjan, Ivory Coast, 2013.

36. Gutman, J.; Sy, A.; Chattopadhyay, S. Financing African Infrastructure: Can the World Deliver? Brookings, Global Economy and Development: Washington, DC, USA, 2015.

37. Baffour Awuah, K.G. Leveraging Rising Land Values to Finance Urban Infrastructure Development in Ghana: A Case Study of Accra; Final Report: UWE/GLGS; University of the West of England: Bristol, UK, 2016.

38. African Development Bank. African Economic Outlook 2021. 2021. Available online: https://www.afdb.org/en/documents/ africaneconomic-outlook-2021 (accessed on 20 November 2021).

39. Jones Lang Lassalle (JLL). Real Estate Transparency Improves in Sub-Saharan Africa. 2014. Available online: www.j1l.com/ Research/JLL_Africa_Transparency_Index.pdf? (accessed on 12 August 2015).

40. JLL. Real Estate Markets Thrive Despite Economic Headwinds. Global Market Perspective, Third Quarter. 2015. Available online: www.jll.com/Research/jllglobal-market-perspective-q3-2015.pdf (accessed on 10 September 2015).

41. Watson, V. Urban Planning and the Future of African Cities. GIM International. 2016. Available online: https://www.giminternational.com/content/article/urban-planning-and-the-future-of-african-cities (accessed on 11 July 2020).

42. Baffour Awuah, K.G.; Morenikeji, O.O. Planning and Governance of Informal Urban Developments in Nigeria; Report submitted to DFID; ICF: London, UK, 2017.

43. Payne, G. Urban Land Development. 2018. Available online: http://newgpa.org.uk/specialisations/urban-land-development/ (accessed on 10 November 2021).

44. World Bank. Land Administration Reform: Part and Parcel of an Inclusive, Resilient, and Sustainable COVID-19 Recovery 2020. Available online: https://blogs.worldbank.org/sustainablecities/land-administration-reform-part-and-parcel-inclusiveresilient-and-sustainable (accessed on 10 September 2021).

45. Makuvaza, S.; Chiwaura, H. African states parties. Support, constraints, challenges, and opportunities for managing cultural world heritage sites in Africa. In The Management of Cultural World Heritage Sites and Development in Africa; Springer: New York, NY, USA, 2014; pp. 45-53.

46. Ndoro, W. World heritage and development in Sub-Saharan Africa. Am. Anthropol. 2017, 119, 129-131. [CrossRef]

47. Baffour Awuah, K.G. Urban development and governance in Nigeria: Challenges, opportunities, and policy direction. Int. Dev. Plan. Rev. 2018, 40, 27-49. [CrossRef]

48. Williams, M.; Gower, R.; Green, J.; Whitebread, E.; Lenkiewicz, Z.; Schröder, P. No Time to Waste: Tackling the Plastic Pollution Crisis before It's Too Late; Tearfund: London, UK, 2019.

49. OECD. Improving Plastics Management: Trends, Policy Responses, and the Role of International Co-Operation and Trade; OECD: Brussels, Belgium, 2018.

50. Duru, R.U.; Ikpeama, E.E.; Ibekwe, J.A. Challenges and prospects of plastic waste management in Nigeria. Waste Dispos. Sustain. Energy 2019, 1, 117-126. [CrossRef]

51. Siddiqui, J.; Pandey, G. A review of plastic waste management strategies. Int. Res. J. Environ. Sci. 2013, 13, 12.

52. National Geographic. The World's Plastic Pollution Crisis Explained. 2019. Available online: https://www.nationalgeographic. com/environment/article/plastic-pollution (accessed on 10 July 2021).

53. Saadat, S.; Rawtani, D.; Hussain, C.M. Environmental perspective of COVID-19. Sci. Total Environ. 2020, 728, 138870. Available online: https:/ / www.sciencedirect.com/science/article/pii/S0048969720323871 (accessed on 20 May 2020). [CrossRef] [PubMed]

54. UNEP. Plastic Waste Causes Financial Damage of US\$13 Billion to Marine Ecosystems each as Concern Grows over Microplastics. 2014. Available online: https://www.unep.org/news-and-stories/press-release/plastic-waste-causes-financial-damage-us13billion-marine-ecosystems (accessed on 20 November 2020).

55. Lucerttini, G.; Musco, F. Circular urban metabolism framework. One Earth 2020, 2, 138-142. [CrossRef] 
56. Borrelle, S.B.; Ringma, J.; Law, K.L.; Monnahan, C.C.; Lebreton, L.; McGivern, A.; Jambeck, J.; Leonard, G.H.; Hilleary, M.A.; Eriksen, M.; et al. Predicted growth in plastic waste exceeds efforts to mitigate plastic pollution. Science 2020, 369, 1515-1518. [CrossRef] [PubMed]

57. World Bank. Trends in Solid Waste Management. 2021. Available online: https://datatopics.worldbank.org/whatwaste/trends_ in_solid_waste_management.html (accessed on 10 November 2021).

58. Udeaja, C.; Trillo, C.; Baffour Awuah, K.G.; Makore, C.B.; Patel, D.; Mansuri, L.; Jha, K. Urban heritage conservation and rapid urbanization: Insights from Surat, India. Sustainability 2020, 12, 2127. [CrossRef]

59. Aburamadan, R.; Trillo, C.; Udeaja, C.; Moustaka, A.; Baffour Awuah, K.G.; Makore, B.C.N. Heritage conservation and digital technologies in Jordan. Digit. Appl. Archaeol. Cult. Herit. 2021, 22, e00197. [CrossRef]

60. Ouma, M. Copyright as an incentive and as a growth driver for digital development: Cultural heritage in the digital era. In Proceedings of the African Ministerial Conference 2015 on Intellectual Property for an Emerging Africa, Dakar, Senegal, 3 November 2015.

61. De la Porte, B.; Higgs, R. Challenges in digitisation of cultural heritage material in the Western Cape, South Africa. S. Afr. J. Inf. Manag. 2019, 21, 1-11. [CrossRef]

62. CTCN-UNEP. Developing Circular Economy Roadmaps for Abating GHG Emissions from the Waste Sector in Zambia. 2021. Available online: https:// www.ctc-n.org/technical-assistance/projects/developing-circular-economy-roadmaps-abating-ghgemissions-waste-0 (accessed on 20 November 2021).

63. Stockholm Environment Institute (SEI). UNEP NDC Waste. 2018. Available online: https://www.sei.org/projects-and-tools/ projects/unep-ndc-waste/ (accessed on 20 November 2021).

64. Berrisford, S.; Cirolia, L.R.; Palmer, I. Land-based financing in sub-Saharan African cities. Environ. Dev. 2018, 30, 35-52. [CrossRef] 